\title{
The Blessing of Whiteness in the Curse of Ham: Reading Gen 9:18-29 in the Antebellum South
}

\author{
Wongi Park
}

check for

updates

Citation: Park, Wongi. 2021. The Blessing of Whiteness in the Curse of Ham: Reading Gen 9:18-29 in the Antebellum South. Religions 12: 928. https://doi.org/10.3390/rel12110928

Academic Editor: Joel Baden

Received: 14 September 2021

Accepted: 19 October 2021

Published: 25 October 202

Publisher's Note: MDPI stays neutral with regard to jurisdictional claims in published maps and institutional affiliations.

Copyright: (C) 2021 by the author. Licensee MDPI, Basel, Switzerland. This article is an open access article distributed under the terms and conditions of the Creative Commons Attribution (CC BY) license (https:/ / creativecommons.org/licenses/by/ $4.0 /)$.
College of Theology and Christian Ministry, Belmont University, Nashville, TN 37212, USA; wongipark1@gmail.com

\begin{abstract}
This essay examines the antebellum history of interpretation surrounding the curse of Ham in Gen 9:18-29. It explores how modern notions of scientific racism were read into the story as a de facto justification for the transatlantic slave trade and the institution of slavery in the antebellum South. However, more than simply being used as a prooftext for racist agendas, the curse of Ham provided a biblical foil for circumscribing a racial hierarchy where whiteness was positioned as superior in the figure of Japheth. By considering key features of the racist antebellum interpretation, I argue that the proslavery rationalization of Christian antebellum writers is rooted in a deracialized whiteness that was biblically produced and blessed with divine authority.
\end{abstract}

Keywords: curse of Ham; Hebrew Bible; antebellum south; slavery; racism; whiteness; critical race theory; whiteness studies; biblical interpretation

The purport of this prophetic denunciation is, that the posterity of Ham would become a degraded, servile race, and eventually fall under the domination of the descendants of his other sons, Shem and Japheth. This extraordinary prediction has been wonderfully verified. The posterity of Shem spread over Asia, while that of Japheth possessed Europe; to whom Ham's posterity, the miserable Africans, have for immemorial ages, been in slavery, either as conquered nations, or as individuals transported to America, by the sons of avarice.

—Simeon Doggett Two Discourses on the Subject of Slavery (Doggett 1835, p. 6)

The root of this negative image of blackness in the English language is traceable to a religio-ethical tradition of associating whiteness with purity and blackness with sin. It is a tradition as old as Plato's narrative vision of the soul or Horace's association of blackness with a power of evil. Blackness has also been perceived as a mark of cursedness because "nearness" to the sun suggested a punishment of some kind. Moreover, in the Christian tradition, white refers to innocence or wisdom (or both) and blackness is tied directly to sin.

—D. Marvin Jones (1997) “The Curse of Ham” (Delgado and Stefancic 1997, p. 255)

\section{Introduction}

Genesis 9:18-29 tells the story of a terse, enigmatic encounter between Noah and his three sons, Shem, Ham, and Japheth. After the floodwaters recede, they leave the ark and step onto dry land. Noah plants a vineyard gets intoxicated with wine and passes out in his tent. Ham lays eyes (וירא, v. 22) on his father's nakedness (ערות אביו, v. 22) and runs out to tell his brothers. Exercising an abundance of caution, Shem and Japheth drape a garment across their shoulders. They walk backward into the tent to avoid eye contact and cover up their naked father. When Noah regains consciousness, he intuitively knows what Ham had done to him (עשה־ל, v. 24). Consequently, Noah performs a speech act of judgment and blessing upon Canaan, Shem, and Japheth: 




(Gen 9:25-27, MT)

He said, "Cursed be Canaan; lowest of slaves shall he be to his brothers".

He also said, "Blessed by the Lord my God be Shem; and let Canaan be his slave.

May God make space for Japheth, and let him live in the tents of Shem; and let Canaan be his slave".

(Gen 9:25-27, NRSV)

Ham's son, Canaan, is hereby cursed as the quintessential slave in bondage to Shem and Japheth, who, along with their descendants, are blessed beyond measure. The story concludes with an editorial comment recording Noah's postdiluvian age and death: "After the flood Noah lived three hundred fifty years. All the days of Noah were nine hundred fifty years; and he died".

The remarkably racist history of interpretation surrounding this little story, despite having no mention of race, makes it one of the most racially charged texts in the Hebrew Bible. Most often referred to as the "curse of Ham," Gen 9:18-29 has been enlisted as a justification for numerous atrocities from the Crusades (Wynter 2003), transatlantic slave trade (Postma 1990; Cannon 2008), Rwandan genocide (Katongole and Wilson-Hartgrove 2009), American slavery and segregation (Haynes 2002). According to David Goldenberg, the story has served as the "single greatest justification for Black slavery for more than a thousand years" (Goldenberg 2003, p. 1).

Furthermore, the racist interpretation of the curse of Ham is not confined to a single religious tradition but spans all three Abrahamic religions alike (for Christian interpretations, see (Peterson 1978; Haynes 2000, 2002); for Jewish interpretations, (Goldenberg 2003); for Muslim interpretations, (Evans 1980, pp. 26-34; Bashir 2019); for debates about the Rabbinic origins of the racist interpretation, see (Copher 1991; Aaron 1995; McKenzie 1997; Alpert 2013)). Arguably, no other sacred text in Christianity, Islam, and Judaism has been misused and abused in the interest of racism more than the curse of Ham in Gen 9:18-29.

\section{Overview of the Argument}

The focus of this essay is on one particular strand of the racist interpretation that emerged in the American South during the antebellum period (1783-1861). I limit my focus on antebellum readings for three reasons.

First, while the racist interpretation is not unique to the Old South, it finds its most overt and notorious expression during the antebellum era. Gen 9:18-29 served as a prooftext and platform in the national debate regarding slavery throughout the 18th and 19th centuries. It was cited in books, pamphlets, sermons, newspapers, and even in-floor proceedings of the US Senate. William Smith (1762-1840), a state senator from South Carolina, is recorded as having said, "this very African race are the descendants of Canaan ... and are still expiating in bondage the curse upon themselves and their progenitors" (Annals of Congress, 15th Congress, first session [6 March 1818]; quoted in (Goldenberg 2017, p. 220)).

Both abolitionists and proslavery advocates used the curse of Ham to argue whether slavery was socially acceptable, morally justified, and biblically warranted. Theodore Dwight Weld (1803-1895), an ardent abolitionist and skilled orator, referred to it as "the vade mecum of slaveholders ... a pocket-piece for sudden occasion, a keepsake to dote over, a charm to spell-bind opposition" (Weld 1838, p. 66). Some antebellum writers identified Black chattel slavery as the prophetic fulfillment of the story that was "so manifestly a blessing in our country, that fugitives from labor are constantly returning to their masters again" (Stringfellow 1856, p. 139). Others such as Rufus L. Perry (1834-1895), a former slave of Smith County, TN, were not at all convinced by the racist interpretation and regarded 
the modern classifications of race as "scientific moonshine" (Perry 1887, p. 7). Both sides of the debate attest to the currency and widespread use of the story. Indeed, so familiar was the curse of Ham that Mark Twain used it as a punchline in Pudd'nhead Wilson without explanation: "He said to himself that the curse of Ham was upon him" ((Twain 1894, pp. 101-2); cf. (Peterson 1978, p. 46); for the curse of Ham motif in Adventures of Huckleberry Finn, see (Elmore and Girardi 2016)).

Second, the American South is the primary context of my teaching and research at Belmont University, a private Christian liberal arts university located south of the MasonDixon line in Nashville, TN. At the center of campus lies the American story of race in brickand-mortar. Originally built by slave labor in 1853, the Belmont Mansion-a popular and historic tourist site in Middle Tennessee-was the summer home of Adelicia Acklen (18171887) and Isaac Franklin (1789-1846) who owned and maintained slaves on the property during the antebellum era (for a biographical overview of Adelicia Acklen, see (JacksonAbernathy 2017)). While Belmont University is not responsible for this history, there is an ethical obligation, particularly as a Christian university in the South, to be responsible stewards. Until very recently, however, this history was not publicly acknowledged by the university in any official capacity. Therefore, a deeper exploration into the complex religious and racial histories of the American South, and the subjacent role of biblical interpretation in the formation of the Bible Belt, provide a contextual interest to explore this topic.

Third, behind Gen 9:18-29 lies an enormous paper trail of interpretive traditions that transcend religious, cultural, ethnic, racial, and geographical borders. While much of this terrain was deftly covered in recent years (for the most comprehensive treatment to date, see (Goldenberg 2003, 2017); for the antebellum period, see (Peterson 1978; Haynes 2002; Johnson 2004; Harvey 2016; Powery and Sadler 2016; Schipper 2020); for the early modern period, see (Kidd 2006; Whitford 2009, 2010); for the medieval period, see (Braude 1997, 2005; Ramey 2014); for a recently completed dissertation on the curse of Ham, see (Reed 2020)), the aim of previous studies is primarily to excavate the origins of blackness or enumerate the biblical justifications for and against slavery. There is far less attention to what these interpretive traditions reveal about the construction of whiteness-and, more specifically, the biblical production of White Christian identity. For these reasons, my main interest is to assess the racist antebellum interpretation from a slightly different angle informed by critical race theory and whiteness studies (Delgado and Stefancic 1997, 2001).

This essay examines the antebellum history of interpretation surrounding the curse of Ham in Gen 9:18-29. It explores how modern notions of scientific racism were read into the story as a de facto justification for the transatlantic slave trade and the institution of slavery in the antebellum South. However, more than simply being used as a prooftext for racist agendas, the curse of Ham provided a biblical foil for circumscribing a social hierarchy of race where whiteness was positioned as superior in the figure of Japheth. By considering key features of the racist antebellum interpretation, I argue that the rationalization of proslavery Christian antebellum writers is rooted in a deracialized whiteness that was biblically produced and blessed with divine authority.

In what follows, I show how Ham was racialized as Black or "blackened" (Jackson 2020) during the antebellum period. Then, I examine the implicit construction of whiteness through the deracialized figure of Japheth. Next, I gesture towards an anti-racist reading to see what, if anything, can be retrieved. Finally, I conclude by reflecting on the critical role of anti-racist and deracializing strategies for grappling with the modern legacy of biblical racism.

\section{The Biblical Divisions of Race in the Antebellum South}

The racist reading of the curse of Ham can be mapped by four common interpretive maneuvers. The first and most important move is a clear and sharp division of races as represented by the sons of Noah and their descendants. Thornton Stringfellow (1788-1869), a Baptist pastor from Virginia and fierce proslavery advocate, wrote several pamphlets to 
advance his proslavery position. Stringfellow begins by citing the curse of Ham as primary evidence:

Noah had three sons, Shem, Ham, and Japheth. These three sons are declared by the Almighty to be types of the several nations that would descend from them. They are made typical representatives of superior, inferior, and medium nations. Their several localities were selected of God for each class of these nations to occupy on the globe, and their habitations were adapted to their type of character (Stringfellow 1861, p. 34, emphasis mine).

According to Stringfellow, the sons of Noah are the progenitors of three groups that comprise all of humanity. Each son functions as an archetype or "typical representations of superior, inferior, and medium nations". Not only do Noah's sons inhabit geographically distinct "localities," their differences are also universal and can be detected by their "type of character". Drawing clear distinctions delineated by race, geography, and character is a crucial first step of the racist interpretation.

Stringfellow is certainly not alone in reading Gen 9:18-29 as dividing humanity into three distinct groups. For instance, William Frederick Van Amringe (1791-1873) reads the story as the basis for dividing humanity into four disparate racial species-Shemitic, Japhetic, Ishmaelitic, and Canaanitic. Each of these racial species is further classified and ranked according to their spiritual character, temperament, and varieties (Van Amringe 1848, pp. 73-76). Writing around the same time on the other side of the globe, John Hanning Speke (1827-1864) maintained a similar four-fold division as Van Amringe. Speke, a British explorer who went on multiple excursions into the interior of Africa, observed with reference to Shem, Ham, Japheth, and Ishmael:

Thus we have four distinct blessings, promises, and curses, pronounced upon the patriarchs of the human family; which were, no doubt, to be typical of their descendants. How were they to be fulfilled? The races must be kept distinct, or they could not be fulfilled (Speke 1864, p. 63, emphasis mine).

Speke goes on to explain why the distinctions between the four groups were of special importance to maintain:

Nothing less than a physical change, - a change of color, - of features, - of manners, habits and mental qualities, - could with certainty operate as an effectual separation. A mere geographical separation, if there were no physical distinction, would only amount to a temporary separation; because the migratory habits of man would soon bring them together. But a geographical separation, together with a physical distinction, would make, as it has made, an almost perfect barrier to an amalgamation of the different species. Thus the promises, curses, and blessings, upon the patriarchs, as types of the several species of mankind, could be literally fulfilled in the descendants of each typical patriarch" (Speke 1864, p. 64, emphasis mine).

Another Southern antebellum writer, Benjamin M. Palmer (1818-1902), a Presbyterian minister who served as the first moderator of the Presbyterian Church in the United States (PCUS), maintained a rigid "law of separation" between races. He wrote:

[T] prevent the admixture of races, these are separated by the occupancy of distinct territory, by opposition of manners, employment and religion, and still more by the power of caste which, as now in India, clearly defined and rendered impassable the boundaries of social life ((Palmer 1856, p. 591); quoted in (Haynes 2000, p. 127)).

Palmer used the curse of Ham extensively in his campaign against abolitionists (Haynes 2000). For Stringfellow, Speke, Palmer, and many others, the sharp distinctions between groups ensured that the blessings and curses of the biblical patriarch would be properly maintained and find fulfillment in their own day.

In some ways modern racial theories were conveniently read into Gen 9:18-29 in a manner that was consistent with the scientific racism of the antebellum period. As 
these examples reveal, differences in human biology were attributed to variations in the environment, geography, and climate. However, in other ways, as in the case of Van Amringe, the curse of Ham became a site for cultivating a uniquely biblical understanding of race. These interpretations made modern notions of race intelligible for a Christian audience by supplying a myth of biblical origins stemming from the patriarchs.

\section{Minoritizing Ham: The Creation and Curse of Blackness}

A second move that follows within the framework of distinct races is racializing Ham as subordinate and inferior. Most proslavery antebellum writers racialize Ham as Black in two ways: either by means of divine creation or as a direct result of the curse. A classic antebellum example of attributing blackness to divine creation is found in the writings of Josiah Priest (1788-1861), a Christian author whose books were widely read and distributed. Priest argues that the skin color of the first human beings was neither white nor black, but originally red. He explains why this must be the case:

If the first two of human kind were created white, they could never have been the parents of black and red men. If they were created red, they could never have been the parents of black and white men. If they were created black, they could never have been the parents of white and red men, as they could naturally procreate only their own complexion (Priest 1852, p. 17, italics original).

To support this theory, Priest cites the work of Josephus (Antiquities of the Jewws, vol. 1) and uses the creation stories in Genesis to infer that Adam's redness is a result of being created out of red clay: "This man was called ADAM, which, in the Hebrew tongue, signifies one that is red, because he was formed of red earth, compounded together, for of that kind is virgin or true earth" (Priest 1852, p. 17; italics original). Offering additional lexical evidence, he explains:

First, ADAM, as above, signifies earthy man; red; second-ADAMAH, signifies red earth, or blood; third-ADAMI, signifies my man red, earthy, human; fourthADMAH, signifies earthy, red, or bloody; all of which words are of the same class, and spring from the same root, which was Adam, signifying red, or copper color (Priest 1852, p. 19; italics original).

After establishing the root and lexical range of the Hebrew word for "human" (אדם), Priest asserts:

Japheth He caused to be born white, differing from the color of his parents, while He caused Ham to be born black, a color still further removed from the red hue of his parents than was white, events and products wholly contrary to nature, in the particular of animal generation, as relates to the human race (Priest 1852, p. 33, emphasis mine).

Priest provides an additional lexical argument for Ham's blackness:

[T] he word Ham, in the language of Noah, which was the pure and most ancient Hebrew, signified any thing that had become black; it was the word for black, whatever the cause of the color might have been, the same as the word black, means black in the English tongue (Priest 1852, p. 33, italics original).

Elsewhere he notes:

Even the word negro, is derived from the Hebrew word Niger, and signifies black. Niger, is a great river of Africa, and was thus originally named, on account of black men having first settled the countries of that river; and hence arose from earliest time the word negro, and applied to the race of Ham, and no other people (Priest 1852, p. 52).

Against the commonly held view that skin color was determined by climate or geography, Priest reasons that Ham's blackness is a product of divine creation or procreation. Since he assumes that blackness is implied by the Hebrew term $ם$ n and is consistent with the geographical origins of African peoples, Priest attributes blackness as a property exclusive 
"to the race of Ham, and no other people". He jumps through several geographical, textual, ethnographic, and linguistic hoops to establish his case.

Other Christian writers of the period linked the origins of blackness to the curse itself. The correlation between curse and color is evident in James A. Sloan, a Presbyterian minister from Mississippi:

Black, restrained, despised, bowed down are the words used to express the condition and place of Ham's children. Bearing the mark of degradation on their skin, they are restrained from being on an equality with their more favored brethren; they are often despised and prevented from intermarrying or mingling with the white and red races, and finally they are bowed down to the authority of their superiors without successful resistance (Sloan 1857, p. 80, emphasis mine).

According to Sloan, black skin palpably expresses "the condition and place of Ham's children". It is a physical "mark of degradation" that renders their subordination to other races visible. Moreover, the descendants of Ham are "despised" and placed in a permanent posture of obeisance; they are "bowed down" to the superior "white and red races". For Doggett, Flournoy, and Sloan, black skin is an indelible mark that signals the accursed and enslaved status of Ham and his descendants.

For others, black skin is not the only physical marker attributed to the curse. Here, the racist imagination of antebellum writers is on full display. Samuel Cartwright (1789-1864) speaks at length describing the physiological differences between the Black and White race:

His lips are immensely thicker than any of the white race, his nose broader and flatter, his chin smaller and more retreating, his foot flatter, broader, larger, and the heel longer, while he has scarcely any calves at all to his legs when compared to an equally healthy and muscular white man. He does not walk flat on his feet but on the outer sides, in consequence of the sole of the foot having a direction inwards, from the legs and thighs being arched outwards and the knees bent. The verb, from which his Hebrew name is derived, points out this flexed position of the knees, and also clearly expresses the servile type of his mind. Ham, the father of Canaan, when translated into plain English, reads that a black man was the father of the slave or knee-bending species of mankind (Elliot 1860, pp. 710-11, emphasis mine).

Cartwright's vulgar description is similar to Van Amringe's assessment of the Canaanitic species. Regarding spiritual character, Van Amringe provides the following list of characterizations:

Attributes equally undeveloped. Inferiorly mental; not originative, inventive, or speculative; roving, revengeful, predatory, and highly sensual; warlike and destructive (Van Amringe 1848, p. 75).

Regarding physical character, he observes:

Sluggish sensibility, approaching to torpor; dark or black skin; hair black, generally woolly; skull compressed on the sides, narrow at the forehead, which slants backwards; cheek bones very prominent; jaws projecting; teeth oblique and chin retreating, forming a muzzle-shaped profile; nose, broad, flat, and confused with the face; eyes prominent; lips thick (Van Amringe 1848, pp. 75-6).

For both Cartwright and Van Amringe, the lips, nose, feet, legs, and knees are part and parcel of the curse. These physical features mirror the inner mind and inferior character of Africans. As seen earlier with Priest, Cartwright bases his interpretation on the Hebrew term for "Canaan" (כנע), which he understands as "the father of the slave or knee-bending species of mankind". Elsewhere, Cartwright renders Canaan as "submissive knee-bender" ((Cartwright 1851, p. 68); quoted in (Peterson 1978, p. 73)). What these examples underscore is that biblical interpretation was not ancillary to the racist thinking that permeated antebellum society. The Bible was an important vehicle in creating and maintaining the racial hierarchy of the American South. 
The move from curse to color is taken a step further in the writings of Stringfellow. He asserts that the curse is manifested by the moral character:

God announced his purpose of subordinating these nations one to another. This subordination was to harmonize with their leading traits of character, and its ultimate object was their general good. The character given of God to each of these three sons, is the character of their descendants at the present moment. Ham was enslaved of God to Shem and Japheth. The propriety of this was first seen in the abuse Ham's descendants made of freedom while they enjoyed it in the land of Canaan. From that day until this, their history proves that freedom to them is a curse, and not a blessing, and that Ham's character is a true type of the character of his descendants (Stringfellow 1861, p. 35, emphasis mine).

For Stringfellow, the curse of blackness is not merely physical; it affects all intellectual, moral, and mental capacities. In this way, Ham's inferior status is passed down through his lineage in the very "character of his descendants". In much the same way, Morgan John Rhys (1760-1804), a Welsh Baptist minister, associated the curse with other physical features including hair: "Where a curse is, a mark you think will follow. The colour, shape, and even the hair on their heads, prove the poor Africans to be children of the curse, and fit for nothing but drudgery and slavery" ((Rhys 1798); quoted in (Goldenberg 2017, p. 219)).

Some antebellum writers clearly opposed the view that Ham's blackness could be the legitimate result of divine creation or Noah's curse. John Rankin, a Presbyterian minister and influential abolitionist from Ohio, suggested that the origin of black skin was ultimately due to climate: "you will find that the blackness of the African is not the horrible mark of Cain, nor the direful effects of Noah's curse, but the mark of a scorching sun" ((Rankin 1833 , p. 8); quoted in (Goldenberg 2017, p. 222; cf. Perry 1887, v)).

Others such as John G. Fee denied any correlation between curse and color reasoning that the curse was placed on Canaan:

Phut settled in Africa, and his posterity and some of the posterity of Cush, as Rollin tells us, migrated westward, and they doubtless were the progenitors of our slaves, but on them no prophetic malediction rested. For the curse was to be upon Canaan, not upon Ham. All the talk we have about the word Ham meaning black, and made so by the curse of the Almighty, is not only without proof-mere assertion-but is futile, because Ham is not the person cursed, but Canaan (Fee 1851, p. 16).

Delegitimatizing the curse on blackness by emphasizing Canaan, not Ham, is evident in many other writings from the antebellum period (Goldenberg 2017, pp. 156-9). For instance, Alexander McLeod (1774-1833), a Presbyterian minister in New York City, wrote:

In order to justify Negro slavery from this prophecy, it will be necessary to prove four things. 1. That all posterity of Canaan were to suffer slavery. 2. That African Negroes are really descended of Canaan. 3. That each of the descendants of Shem and Japheth has a moral right to reduce any of them to servitude. 4 . That every slaveholder is really descended from Shem or Japheth. Want of proof in any of these particulars will invalidate the whole objection. In a practice so contrary to the general principles of the divine law, a very express grant from the supreme authority is the only sanction to us. But not one of the four facts specified as necessary can be supported with unquestionable documents (McLeod 1863, pp. 27-8).

Many other Christian abolitionists vehemently opposed the racist interpretation of the curse of Ham as a justification for the origins of blackness and the institution of slaveryincluding, John Rankin, David Lee Child, and James W. C. Pennington ((Goldenberg 2017, pp. 222-4); see also (Peterson 1978, pp. 46-48)). 


\section{Blessing Japheth: The Dominion and Domain of Whiteness}

A third move directly proportional to the subordination of Ham is the elevation of Japheth. Just as Ham is made subordinate and inferior, Japheth and his descendants are endowed with power and authority. According to Palmer, Japheth is bestowed with superior qualities and characteristics:

Japhet and his race ... seem designated to be the organ of human civilization, in cultivating the intellectual powers. Dividing historically into two great branches, the Japhetic whites, spreading over the diversified continent of Europe, through a protracted discipline develope [sic] the higher powers of the soul in politics, jurisprudence, science, and art: while the Asiatic Japhetites dispersed over a more monotonous continent, embark in those pursuits of industry fitted to the lower capacities of our nature ((Palmer 1859, p. 5); quoted in (Haynes 2000, p. 127, emphasis mine)).

Japheth and his descendants are the blessed recipients of higher faculties uniquely suited for politics, jurisprudence, science, and art. Sometimes this move is framed in a backhanded way to harp on Ham's inferiority. For example, Priest insinuates the inherent superiority of Shem and Japheth and the races they represent in the following:

As to the mental character of the black nations, considered collectively, we have found them, in all ages, since their appearance on the earth, of but small account when compared with the other races of men, the red and white (Priest 1852, v, emphasis mine).

In contrast to the "small" mental character of Ham and his African descendants, Stringfellow characterizes Japheth as possessing a far superior intellect:

The descendants of Japheth were distinguished for a progressive intelligence, and a commanding influence upon the destinies of the world. These qualities were to give them dominion in the tents of Shem, and the descendants of Ham were made their servants. And this future elevation of Japheth to the dominion of the world, was to harmonize with supreme reverence for that God whom they had been brought to know by dwelling in the tents of Shem, whose God was the eternal I AM, and not dumb idols (Stringfellow 1861, p. 12, emphasis mine).

Stringfellow identifies a two-fold process at work. First, the need to exercise dominion arises out of the fact that blackness is dehumanized as partly human, sub-human, or less-than-human. Japheth's superior status must be exercised for the sake of Ham. He reasons:

There is a great physical, moral, and intellectual difference between the two races. The tendency upon each race of the same set of circumstances, does not diminish, but increases this difference through life. The age of twenty-one, which gives bodily maturity to both races, develops moral and intellectual manhood in the white race, while the African remains, at the end of that time, a mere child in intellectual and moral development, perfectly incapable of performing the great functions of social life (Stringfellow 1861, p. 10).

For Stringfellow, enslavement is a necessary means of bringing the African race to full maturity. Second, the need to exercise dominion is equally necessary for Japheth and his descendants. Here, again, Stringfellow writes:

This remarkable fact of legislative silence for the protection of slaves, can only be accounted for by supposing, what we of the South know to be true, that the relation of master and slave, which God ordained between the superior races of Shem and Japheth and the inferior race of Ham, was a relation that in the nature of things constituted the strongest guarantee, which can bind the superior to take care of the inferior man" (Stringfellow 1861, p. 30).

Here, Stringfellow connects status and function; to rule over those who are inferior is the blessing and burden of Japheth. Moreover, Japheth's inherent superiority is attached to 
his biblical name. According to Cartwright, "the white man bore the name of Japheth in the Bible, and the negro that of Canaan; and that the negro's servile nature was expressed in his Hebrew name" (Elliot 1860, p. 883). This blessing is one that will continue to grow and expand: "The Bible tells in unmistakable terms that Japheth, or the white race, was to be enlarged" (Elliot 1860, p. 883).

However, not all antebellum interpretations agree on who or what defines the figure of Japheth. In fact, Shem, Ham, and Japheth are all signified in multiple ways throughout the antebellum period. Sometimes they represent races (Mongoloid, Negroid, Caucasoid) or nations (Europe, Asia, Africa). Other times they represent geography (east, south, north) or skin color (sometimes brown or yellow, particularly in Europe, but most often red, black, and white in the antebellum South). Regardless of how each group is defined, there is a consistent pattern among antebellum interpretations: Whiteness is placed in a position of dominance at the top of the racial hierarchy, while blackness is minoritized in a subordinate position at the bottom. Indeed, so strong is the polarity between Japheth and Ham that Shem is often undervalued, overlooked, or entirely omitted from antebellum interpretations:

In most versions of the Ham myth Noah's third son, Shem, who was the progenitor of the red race, was only a minor character. Since the contact between Indians and whites in the antebellum South was only marginal, the myth did not provide a detailed model for their relations in the same way that it prescribed the proper roles between blacks and whites (Peterson 1978, pp. 7-8).

Despite differences in variation, order, and arrangement, the ascendant ranking of White-over-Black is a consistent pattern of the racist antebellum interpretation.

\section{Race as Divine Decree}

The fourth and final move of the racist antebellum interpretation is authorizing its veracity by appealing to race as a divinely inspired performative decree. Many antebellum writers genuinely believed that race had biblical origins as the direct fulfillment of biblical prophecy. Philip Schaff (1819-1893), who studied at Tübingen under the influence of F.C. Baur, wrote:

Slavery, like despotism, war, and all kinds of oppression, existed no doubt long before the deluge, which was sent upon the earth because it was 'filled with violence' (Gen. vi. 11). But it is not expressly mentioned till after the flood, in the remarkable prophecy of Noah, uttered more than four thousand years ago and reaching in its fulfillment, or at least in its applicability, even to our time and country (Schaff 1861, p. 4, emphasis mine).

Schaff, a professor of church history at Mercersburg Theological Seminary in Philadelphia, identifies moments in Israel's history where Noah's prophecy is in various stages of fulfillment. Reading Gen 9:18-29 as prophecy—rather than as ancient history, narrative, legend, or myth-enabled him to draw a straight line from the biblical patriarchs to his own day. He continued:

But in point of fact both the curse and the blessing of Noah extend still further and justify a wider historical application. The curse of involuntary servitude, which in the text is confined to the youngest son of Canaan because of his close contact with the Israelites, has affected nearly the whole of the posterity of Ham, or those unfortunate African races which for many centuries have groaned and are still groaning under the despotic rule of the Romans, the Saracens, the Turks, and even those Christian nations who engaged in the iniquity of the African slave trade (Schaff 1861, p. 6).

Schaff clearly acknowledges slavery as immoral here and elsewhere (Schaff 1861, pp. 3-5). Nevertheless, there is an underlying theological determinism that drives and necessitates "the iniquity of the African slave trade". The biblical necessity for slavery is further expressed in the following: 
Whether we connect it with this ancient prophecy or not, it is simply a fact which no one can deny, that the negro to this day is a servant of servants in our own midst... Slavery then is represented from the start as a punishment and a curse and is continued as such from generation to generation for these four thousand years, falling with special severity upon the African race, and involving the innocent with the guilty (Schaff 1861, pp. 6-7, emphasis mine).

What is striking here is the framing of Noah's prophecy, uttered four thousand years earlier in Schaff's estimation, as a direct path to antebellum slavery. While Schaff acknowledges slavery as immoral, his belief that it is divinely foreordained effectively conceals, overshadows, and justifies its existence. This comes across subtly in the way he spiritualizes slavery as the epitome of sin:

Sin is the first and worst kind of slavery, and the fruitful source of every other intellectual, moral, and physical degradation. In this sense every sinner is a slave to his own appetites and passions, and can only attain to true freedom by the Christian salvation (Schaff 1861, p. 3).

This sentiment is made even more explicit elsewhere:

Civil bondage may be a great evil, but not near as great as the moral bondage of sin; civil freedom may be a great good, but only temporal at best, and not to be compared with the spiritual freedom which elevates the humblest Christian slave far above his heathen master. All earthly distinctions and blessings vanish into utter insignificance when compared with the eternal realities of the kingdom of heaven (Schaff 1861, p. 25, emphasis mine).

Schaff's reading of Gen 9:18-29 is a reluctant acceptance of slavery as immoral but theologically necessary. For Schaff, what is spiritual and eternal supersedes what is social and temporal, thereby softening-if not altogether excusing-the heinous and dehumanizing conditions of slavery. John Flournoy (1808-1879), who advocated for the relocation of antebellum slaves to Liberia, likewise attributed Black slavery to prophecy: "The blacks were originally designed to vassalage by the Patriarch Noah" ((Flournoy 1838, p. 16); quoted in (Goldenberg 2003, p. 1)). As abhorrent as Black chattel slavery may be, according to Schaff and Flournoy, it is simply a matter of course-an inevitable fulfillment of biblical prophecy.

Other antebellum writers upped the ante by arguing that antebellum slavery was not merely a result of Noah's prophecy, but a divinely inspired and sanctioned institution. With reference to Genesis 9, Stringfellow explained:

Here language is used, showing the favor which God would exercise to the posterity of Shem and Japheth, while they were holding the posterity of Ham in a state of abject bondage. May it not be said in truth, that God decreed this institution before it existed; and has he not connected its existence, with prophetic tokens of special favor, to those who should be slave owners or masters? He is the same God now, that he was when he gave these views of his moral character to the world; and unless the posterity of Shem and Japheth, from whom have sprung the Jews, and all the nations of Europe and America, and a great part of Asia, (the African race that is in them excepted)-I say, unless they are all dead, as well as the Canaanites or Africans, who descended from Ham, then it is quite possible that his favor may now be found with one class of men, who are holding another class in bondage. Be this as it may, God decreed slavery-and shows in that decree, tokens of good-will to the master (Stringfellow 1841, p. 2, emphasis mine).

Stringfellow's sentiments are not unlike the theological determinism expressed by Schaff. However, he goes a step further by appealing to the notion of predestination that "God decreed this institution before it existed". For Stringfellow, antebellum slavery was predestined by God long before the beginning of time. It is a sacred institution and solemn Christian duty: "The guardianship and control of the black race, by the white, in this Union, is an 
indispensable Christian duty, to which we must as yet look, if we would secure the well-being of both races" (Stringfellow 1856, p. 105, emphasis mine).

The performative nature of race as a divine decree is coupled with biblical and ministerial authority. Elsewhere, he writes: "I have shown by the Bible, that God decreed this relation between the posterity of Canaan, and the posterity of Shem and Japheth" (Stringfellow 1856, p. 81). Likewise, Simeon Doggett (1765-1852), a Unitarian minister in Raynham MA, employs the language of fate, destiny, and divine authority: "The doom of Ham has been branded on the form and features of his African descendants. The hand of fate has united his color and destiny. Man cannot separate what God hath joined" (Doggett 1835, p. 6, emphasis mine). As these examples indicate, antebellum writers frequently cited the curse of Ham to bolster the claim that Black slavery was a divine decree blessed by God that could never ever be changed.

\section{Reading against the Racist Interpretation of Gen 9:18-29}

In view of the preceding, developing an anti-racist reading of the curse of Ham is no small task. It involves reading through, around, and against the antebellum interpretation of Gen 9:18-29. What is problematic about the racist interpretation? Is there any merit to it? How is it possible to address and undo the damaging legacy of this text? Developing an anti-racist reading also requires sifting through the significance of the racist interpretation. Where did it come from? How has it been reproduced? What are its lingering effects? What does the racist interpretation say about the construction of race during the antebellum period? Providing a preliminary response to these questions is necessary for moving the discussion forward.

There are numerous deficiencies that beleaguer the racist interpretation. The first and most obvious problem is the assertion that the curse is divinely decreed. This is inaccurate based on a surface-level reading of the text. The last time the divine being speaks in the story of Noah is Gen 9:17: "God (אלהים) said to Noah, 'This is the sign of the covenant that I have established between me and all flesh that is on the earth."' The curse is emphatically not uttered by God; it is uttered by a hungover Noah who was perhaps angered at and humiliated by his son.

A second issue is a mismatch between the alleged crime and punishment. The consequence of perpetual slavery, according to the antebellum interpretation, far outweighs the demerits of Ham's crime. Many theories have been offered regarding the precise nature of Ham's misconduct to explain the discrepancy between the misdeed and curse. These explanations range from voyeurism, castration, paternal incest, and maternal incest (Bergsma and Hahn 2005). In any case, none of these alleged crimes warrant perpetual servitude.

A third liability is a faulty conception of race as a distinct biological reality. Dividing humanity into distinct races has been debunked as a modern myth. Race has no biological or genetic basis in blood or DNA. Yet many antebellum writers relied on this deficient premise not only in their reading of the curse of Ham, but also in other social, scientific, and legal arrangements from ethnology to eugenics (see further Sussman 2014).

A fourth problem that hinders the antebellum interpretation is signifying Shem, Ham, and Japheth with modern nation-states (Asia, Africa, and Europe, respectively). This is a modern idea mapped onto the story that has no bearing on the ancient world and directly conflicts with the tribal genealogies and kinship affiliations expressed in the Table of Nations in Gen 10. As Ronald Hendel (2013, p. 200) notes with reference to the Table of Nations in Genesis 10:15-18, "These are all Canaanite peoples, who lived in western Asia. The later use of this passage to justify the enslavement of Africans is simply wrong, a misreading of the plain text of Genesis". While Gen 10:6ff draws a connection between Ham and other peoples with darker skin (Cush and Put), the underlying connection is ideologically motivated to associate Ham with the enemies of Israel in Canaan and Egypt (Ps 78:51; Frankel 2021). However, the ethnic boundaries in biblical genealogies are permeable and subject to ethnic fission and fusion (McEntire and Park 2021). 
But perhaps the major flaw of the racist interpretation is that there is no reference to color in Gen 9:18-29. Ham does not have black skin just as Japheth does not have white skin. No such connection to color or connotation of skin tone can be inferred by the Hebrew term "Ham" (ח). According to many standard Hebrew lexicons, the term implies heat or warmth (Gen 8:22; Jer 17:8; Job 24:19) or hot bread (Josh 9:12; 1 Sam 21:7). It can refer to a personal name in Western Semitic. The term rמא refers to anger, fury, or rage (Dan 3:13, 19). Similarly, the term יחם refers to the heat of anger or vengeance (Deut 19:6; Job 6:7). These terms do not refer to blackness as a color or racial/ethnic signifier. The term שחר, by contrast, is used to denote black skin (Song 1:5; Job 30:30; Lam 5:10). These references are less an aesthetic commentary about black skin and more a judgment about unhealthy skin that was darkened by labor in the sun (Sadler 2005, p. 91; cf. Sadler 2006). The NRSV translates Song 1:5 as "I am black and beautiful". For modern readers, the term "black" dually signifies color and race. Hence a better translation of שחר in Song 1:5 that highlights the context of the Shulamite's work as a laborer is: "I am dark but beautiful" or "I am burnt but beautiful" (Bellis 2021).

All of these examples show the semantic field of terms connoting anger, heat, darkness, and sun burnt. The notion of blackness as color, race, or ethnicity is absent in the text of Gen 9:18-29. Ham is not Black. He is therefore made Black or "blackened" (Jackson 2020) into existence in and through the racist antebellum interpretation. Similarly, the notion of whiteness as color, race, or ethnicity is absent in the text of Gen 9:18-29. Japheth is not White. He is made White through the racist antebellum interpretation.

What, then, does the racist antebellum interpretation say about blackness during the antebellum period? Technically speaking, not much at all. In fact, it says very little beyond the fact that blackness was ipso facto racialized by Southern writers who appealed to the story in problematic ways. However, if the creation and curse of blackness is an antebellum myth that does not hold water, then a different line of questioning is necessary. That is, if race is a socially constructed category that has no legitimate biological or biblical basis, then an ideological turn in the argument is necessary. From this vantage point, the racist interpretation says far more about White Southerners - their self-perceptions and racialized views of others-than it does about Black Southern identity during the antebellum period.

To come at this point from a different angle, a central axiom of critical race theory is the social construction of race. Since it was shown that there is greater genetic variation within rather than between races, the entire modern system of racial classification is rendered arbitrary. As a social construction, race is better understood as a signifying discourse that moves in two simultaneous, if unequal, directions. Theoretically, any act whereby the dominant-self mobilizes racial/ethnic markers (i.e., skin color, hair, language) to signify the minoritized-other through racialization entails a parallel process of deracialization. By explicitly racializing the minoritized other as inferior, the dominant-self implicitly deracializes itself as superior. Consequently, the racialization of Ham reveals more about how whiteness was deracialized into existence.

Referring to 18th and 19th-century constructions as deracialized whiteness may seem anachronistic. This is especially true when one considers that critical race theory and whiteness studies emerged in the 1990s. Clearly, for many antebellum writers, whiteness is not deraced but classified as one of several races. However, the terminology of deracialization does not imply that whiteness is not racialized; it suggests that whiteness is implicitly racialized in a particular way on a sliding scale at the opposite end of the racializing spectrum. The deracializing process increases the degree of superiority and dominance for the self, while the racializing process decreases the degree of inferiority and minoritization for the other. Therefore, racialization and deracialization are two sides of the same coin. According to this understanding, race is best understood as a signifying discourse and dialectic of self and other that ascribes inferiority and superiority to varying degrees and in varying ways (for more on a theory of deracialization, see Park 2019).

Practically speaking, what this means for our purposes is that the racist antebellum interpretation says far more about the deracialized construction of whiteness than it does 
about Black Southern identity. Hence, instead of highlighting Black and Slave-to borrow the title of David Goldenberg's book - what are the implications for understanding the racist reading through the lens of White and Master? To that end, I offer three characterizations about the construction of whiteness that can be detected in the antebellum interpretation.

First and foremost, the racist interpretation is undergirded by the construction of whiteness that is biblically produced. This is one of the defining features of the antebellum reading of the curse of Ham. Rather than appealing to other popular explanations, antebellum writers turned specifically to the Christian Bible to make sense of the origins of race. As Charles A. Gallagher notes,

The classification of the earth's population into racial categories ostensibly based on sound scientific principles was nothing more than the religious dogma of the day given a veneer of respectability by the scientific community. Almost every scientific theory that justified and normalized white over non-white had some rationalization, empirical starting point, or assumption based in Holy Scripture. The supposed essential races of mankind (Negroid, Mongoloid, and Caucasoid) and which groups were destined to dominate becomes a scientific retelling of the curse of Ham, manifest destiny, and God's will that heathens (anyone not white and Christian) must be converted, controlled, or eliminated. Science confirmed what Christian theologians knew all along: The white race was God's chosen people and as such had the right to claim all natural resources and to subjugate any population deemed culturally inferior, heathen, pagan, or uncivilized (Gallagher 2007, p. 11).

The Bible played a central role in producing a particular view of whiteness as biblically warranted, distinct, and superior to all other races. Underlying this conception of race is a perspective that asserts the superiority of whiteness as distinct, genealogical, and universal-all of which was made possible at the expense of Ham and his descendants. The biblical inflection on whiteness and race can be further appreciated in how White Southerners almost always aligned themselves with the biblical protagonist-be it Noah, Japheth, or Israel. By contrast, blackness was virtually always identified with the enemies of Israel, the Canaanites, through the line of Ham.

Second, the biblical construction of whiteness as superior is fully dependent upon a demeaning stereotype of black inferiority. White antebellum writers, in the very act of racializing blackness as accursed and enslaved, were unwittingly signifying themselves as blessed and free. Indeed, the latter was wholly dependent upon the former. As Toni Morrison explains:

The rights of man, for example, an organizing principle upon which the nation was founded, was inevitably yoked to Africanism. Its history, its origin is permanently allied with another seductive concept: the hierarchy of race. As the sociologist Orlando Patterson has noted, we should not be surprised that the Enlightenment could accommodate slavery; we should be surprised if it had not. The concept of freedom did not emerge in a vacuum. Nothing highlighted freedom - if it did not in fact create it—like slavery" (Delgado and Stefancic 1997, p. 82).

The American blessing of freedom only exists in relation to the antebellum curse of slavery. The notion of freedom was conceived within a distinct framework of racial hierarchies that bound whiteness inextricably to blackness. Within this schema, a biblically inflected whiteness is the product, not the cause, of slavery. As Karen Teel explains:

Whiteness has developed through a long and tortuous history ... a history that some scholars contend has its root in an ancient and fundamental perversion of Christianity's Jewish origins. There can be no doubt that it began at least as long ago as the European Christians who, even before thinking of themselves as 'white,' created the U.S. system of race-based slavery. 'Whiteness' is a properly and 
peculiarly white Christian theological problem that demands a white theological response (Teel 2012, p. 20).

Racial identities do not exist in a vacuum but are always already relational, dialectical, and historically situated. As blackness was racialized during the antebellum period as cursed, bound, and dependent, whiteness was simultaneously deracialized as blessed, free, and independent. In this way, whiteness is fully reliant upon and indebted to a caricature of blackness as its deracialized antithesis.

Third, the biblical construction of whiteness naturalizes white skin as a marker of divine beatitude and blessing. There is a distinct pattern at work in antebellum interpretations. Whiteness is divinized, while blackness is dehumanized: "Whiteness exists not only as the opposite of non-Whiteness, but as the superior opposite" (Haney-López 2006, p. 20). Whiteness is thereby afforded a superior rank, position, and status in the hierarchy of races. The divinization of whiteness and dehumanization of blackness are evident in several legal formulations that defined slavery and blackness such as the Three-Fifths Compromise (1787). Another legal formulation was the one-drop rule, first adopted in Tennessee in 1910. According to this law, if it was deemed that a person had one drop of African blood, that person was regarded as a Negro or colored person (for a historical overview of the one-drop rule, see: (Sweet 2005)). The 1920 Census, assuming the one-drop rule, defined White as follows:

The term 'white' as used in the census report refers to person understood to be pure-blooded whited. A person of mixed blood is classified according to the nonwhite racial strain or, if the nonwhite blood itself is mixed, according to his racial status as adjudged by the community in which he resides ((U.S. Census Bureau 1922, p. 10); quoted in (Liz 2018, p. 251)).

The racist interpretation of the story relies upon a myth of White racial purity, which is ultimately what the one-drop rule was designed to protect. Curiously, there is no one-drop rule for the legal definition of whiteness (Delgado and Stefancic 1997, p. xvii). Part of the reason for this lies in the fact that "Whites are those with no known African or other non-White ancestry ... Whites exist as a category of people subject to a double negative: they are those who are not non-White" (Haney-López 2006, p. 20).

The racist interpretation of the curse of Ham had profound and long-lasting effects (Knust 2014). The origins stem from the "beginning of the Atlantic slave trade in the fifteenth century Black and slave were inextricably joined in the Christian mind" (Goldenberg 2003, p. 3). In fact, it was so pervasive during the antebellum period that its strength could be seen even by those who opposed it. Perry, a former slave from Tennessee, produced a study of ancient literature to counter the racist interpretation, showing how the ancient Cushites of Africa were among the world's leading experts in art, science, and theology. He wrote:

[The Cushite/Hamitic family] has had a checkered life, it is true; but so have the Shemitic and Japhetic families. He has been a master and he has been a slave; but this is no less true of Shem and Japheth. In the world's history of the rise and fall of nations, no race, no color, can boast of exemption from misfortune. But no race can boast of a higher celebrity in ancient times than the Negro, then called Cushites by the Hebrews, and Ethiopians by the Greeks (Perry 1887, p. 29, emphasis mine).

Perry concluded his study with an exhortation:

Now what the Cushite was, certainly has some bearing on an intelligent judgment of what he is, and he is to be. It should inspire the Africo-American with an ambition to emulate his forefathers; for if to the memory of the distinguished Negroes of modern times we add the historic facts reaching from Menes to the Christian era concerning the greatness of the ancient Cushites, of whom we are lineal descendants, it were pusillanimous in us, and dishonoring to our ancestors, to be ashamed of either our color or our name (Perry 1887, p. 31). 
The lingering effects of the racist interpretation can be seen in the writings of W.E.B. Du Bois. In Darkwater: Voices from Within the Veil, playing devil's advocate, he imagines what his white interlocutor might say to him invoking the racist interpretation of the curse of Ham:

This assumption that of all the hues of God whiteness alone is inherently and obviously better than brownness or tan leads to curious acts; even the sweeter souls of the dominant world as they discourse with me on weather, weal, and woe are continually playing above their actual words an obligato of tune and tone, saying: "My poor, un-white thing! Weep not nor rage. I know, too well, that the curse of God lies heavy on you. Why? That is not for me to say, but be brave! Do your work in your lowly sphere, praying the good Lord that into heaven above, where all is love, you may, one day, be born-white!" (Du Bois 1920, p. 30).

The wide-reaching influence of the racist interpretation can be felt in the writings of prominent African Americans who accepted the dominant narrative long after the antebellum period. For instance, James Baldwin in The Fire Next Time wrote:

I realized that the Bible had been written by white men. I knew that, according to many Christians, I was a descendant of Ham, who had been cursed, and that I was therefore predestined to be a slave. This had nothing to do with anything I was, or contained, or could become; my fate had been sealed for ever, from the beginning of time. And it seemed, indeed, when one looked out over Christendom, that this was what Christendom effectively believed (Baldwin 1962, p. 46).

Later he writes:

In the same way that we, for white people, were the descendants of Ham, and were cursed for ever, white people were, for us, the descendants of Cain (Baldwin 1962, p. 51; quoted in (Junior 2020, p. 673).

The epigraph at the beginning of this essay by D. Marvin Jones highlights the effects of the racist interpretation in the negative association attached to blackness and the positive association to whiteness. These are a few of the many examples that show the wide-ranging influence of the antebellum interpretation of the curse of Ham.

\section{Conclusions}

In sum, a distinctly biblical notion of race emerged during the antebellum period. This understanding is by and large consistent with popular racial theories of the day. However, it differed insofar as it explained the origins of race not by climate, geography, or any other popular racial theory. Instead, it traced and attached the origins of race to a biblical myth going all the way back to Noah and his sons representing three racial archetypes. Within this framework of distinct races, the antebellum interpretation racialized Ham and his descendants as Black in one of two ways: by divine creation or on account of the curse itself. For some antebellum writers, the physical effects of the curse involved other features beyond skin color such as hair. For others, the curse extended into the very character, mind, and personhood of Ham and his descendants.

At the same time, whiteness was elevated in the deracialized figure of Japheth. Japheth represented a different kind of race in opposition to blackness, an idealized and blessed form of humanity superior to Ham in every conceivable way. This blessing came with a cost for White Southerners to care and provide for the enslaved descendants of Ham. The racist interpretation blessed the antebellum institution of slavery under the banner of biblical prophecy and divine authority. Regardless of how blackness is defined, or the precise origins of black skin explained, the antebellum interpretation subjects Ham-and all African peoples by implication - to a curse that sanctified the antebellum practice of slavery as a divinely decreed institution. The rhetorical force of attributing the curse to biblical and divine authority is unmistakable. For if the basis for the claim is social, then it 
is open to revision. However, if the basis is divinely authorized, then the inferior status of the racialized subject is forever fixed and cannot be changed. It is a "scheme calculated to fix difference forever, to secure discursive closure" (Mirón and Inda 2000, p. 85). In this way, blackness is forever cursed, while whiteness becomes eternally blessed.

According to Ibram X. Kendi, racial inequity exists any time "when two or more racial groups are not standing on approximately equal footing" (Kendi 2016, p. 18). Similarly, a racist policy can be spotted as "any measure that produces or sustains racial inequity between racial groups" that broadly includes "written and unwritten laws, rules, procedures, processes, regulations, and guidelines that govern people" (Kendi 2016, p. 18). However, perhaps more relevant is Kendi's notion that even thoughts and ideas can be racist: "A racist idea is any idea that suggests one racial group is inferior to or superior to another racial group in any way. Racist ideas argue that the inferiorities and superiorities of racial groups explain racial inequities in society" (Kendi 2016, p. 20). If Kendi is right that inequities exist because of racist policies and racist ideas, then Gen 9:18-29 may be one of the most racially volatile texts in all of biblical literature.

What is the public role of biblical scholarship in addressing flagrant abuses in the history of interpretation? What responsibilities do Christian institutions bear in acknowledging the ills of the past? What role ought biblical scholars play in addressing the historical uses, misuses, and abuses of biblical texts? Beneath these questions lies an ethical responsibility to address and challenge the modern legacy of biblical racism. The proclivity to classify, differentiate, and rank groups within a hierarchy is a perennial issue with ancient roots, modern parallels, and global implications. It taps into a primordial desire that is essential and fundamental to human existence. Indeed, if the modern legacy of racism was biblically produced, then biblical scholars have an ethical responsibility to reflect on foundational questions of meaning and identity that are central to human flourishing.

Funding: This research received no external funding.

Acknowledgments: Generous help from Joel Baden, Mark G. Brett, Mark Brown, Heather Finch, Nyasha Junior, Mark McEntire, Gypsy Moody, Justin Reed, and Beth Ritter-Conn is gratefully acknowledged.

Conflicts of Interest: The author declares no conflict of interest.

Dedication: This essay is dedicated in loving memory of Rev. Thomas and Charlie McKenzie.

\section{References}

Aaron, David H. 1995. Early Rabbinic Exegesis on Noah's Son Ham and the So-Called "Hamitic Myth". Journal of the American Academy of Religion 63: 721-60. [CrossRef]

Alpert, Rebecca. 2013. Translating Rabbinic Texts on the Curse of Ham: What We Learn from Charles Copher and His Critics. In RePresenting Texts: Jewish and Black Biblical Interpretation. Edited by Rachel Adelman, Rebecca Alpert, Wil Gafney, Jamal-Dominique Hopkins, Laura S. Lieber, W. David Nelson and Stacy Davis. Piscataway: Gorgias Press, pp. $29-42$.

Baldwin, James. 1962. The Fire Next Time. London: Michael Joseph.

Bashir, Haroon. 2019. Black Excellence and the Curse of Ham: Debating Race and Slavery in the Islamic Tradition. ReOrient 5: 92-116. [CrossRef]

Bellis, Alice Ogden. 2021. I am Burn but Beautiful: Translating Song 1:5a. Journal of Biblical Literature 140: 91-111. [CrossRef]

Bergsma, John Sietze, and Scott Walker Hahn. 2005. Noah's Nakedness and the Curse on Canaan (Genesis 9:20-27). Journal of Biblical Literature 124: 25-40. [CrossRef]

Braude, Benjamin. 1997. The Sons of Noah and the Construction of Ethnic and Geographical Identities in the Medieval and Early Modern Periods. The William and Mary Quarterly 54: 103-42. [CrossRef]

Braude, Benjamin. 2005. Michelangelo and the Curse of Ham: From a Typology of Jew-Hatred to a Genealogy of Racism. In Writing Race across the Atlantic World. Edited by Phillip D. Beidler and Gary Taylor. New York: Palgrave MacMillan, pp. 79-92.

Cannon, Katie Geneva. 2008. Christian Imperialism and the Transatlantic Slave Trade. Journal of Feminist Studies in Religion 24: 127-34. [CrossRef]

Cartwright, Samuel Adolphus. 1851. Diseases and Peculiarities of the Negro Race, Part 1. De Bow's Review 11: 64-69.

Copher, Charles B. 1991. The Black Presence in the Old Testament. In Stony the Road We Trod: African Americans and Biblical Interpretation. Edited by Cain Hope Felder. Minneapolis: Fortress Press, pp. 146-64.

Delgado, Richard, and Jean Stefancic, eds. 1997. Critical White Studies: Looking Behind the Mirror. Philadelphia: Temple University Press. 
Delgado, Richard, and Jean Stefancic, eds. 2001. Critical Race Theory: An Introduction. New York: New York University Press.

Doggett, Simeon. 1835. Two Discourses on the Subject of Slavery. Boston: Cornell University Library.

Du Bois, William Edward Burghardt. 1920. Darkwater: Voices from within the Veil. New York: Harcourt, Brace and Company.

Elliot, E. N. 1860. Cotton Is King, and Pro-Slavery Arguments: Comprising the Writings of Hammond, Harper, Christy, Stringfellow, Hodge, Bledsoe, and Cartwright, on This Important Subject. Augusta: Pritchard, Abbott \& Loomis.

Elmore, Jenifer, and C. Dale Girardi. 2016. Reversing the Curse: Slavery, Child Abuse, and Huckleberry Finn. American Literary Realism 49: 1-20. [CrossRef]

Evans, William McKee. 1980. From the Land of Canaan to the Land of Guinea: The Strange Odyssey of the "Sons of Ham". The American Historical Review 85: 15-43. [CrossRef]

Fee, John Gregg. 1851. The sinfulness of slaveholding shown by appeals to reason and Scripture. New York: J. A. Gray.

Flournoy, John Jacobus. 1838. A Reply to a Pamphlet, Entitled Bondage, a Moral Institution Sanctioned by the Scriptures and the Savior. Whitefish: Kessinger Publishing, LLC.

Frankel, David. 2021. Noah's Drunkenness and the Curse of Canaan: A New Approach. Journal of Biblical Literature 140: 49-68.

Gallagher, Charles A. 2007. White. In Handbook of the Sociology of Racial and Ethnic Relations. Edited by Hernan Vera and Joe R. Feagin. New York: Springer, pp. 9-14.

Goldenberg, David M. 2003. The Curse of Ham: Race and Slavery in Early Judaism, Christianity, and Islam. Princeton: Princeton University Press.

Goldenberg, David M. 2017. Black and Slave: The Origins and History of the Curse of Ham. Berlin: DeGruyter.

Haney-López, Ian. 2006. White by Law: The Legal Construction of Race. New York: New York University Press.

Harvey, Paul. 2016. Christianity and Race in the American South: A History. Chicago: The University of Chicago Press.

Haynes, Stephen R. 2000. Race, National Destiny, and the Sons of Noah in the Thought of Benjamin M. Palmer. Journal of Presbyterian History 78: 125-43.

Haynes, Stephen R. 2002. Noah's Curse: The Biblical Justification of American Slavery. Oxford: Oxford University Press.

Hendel, Ronald. 2013. The Book of Genesis A Biography. Princeton: Princeton University Press.

Jackson, Zakiyyah Iman. 2020. Becoming Human Matter and Meaning in an Antiblack World. New York: NYU Press.

Jackson-Abernathy, Brenda. 2017. Adelicia Acklen: Beyond the "Belmont" Legend and Lore. Tennessee Historical Quarterly 76: 2-43.

Johnson, Sylvester A. 2004. The Myth of Ham in Nineteenth-Century American Christianity: Race, Heathens, and the People of God. New York: Palgrave MacMillan.

Jones, D. Marvin. 1997. The Curse of Ham. In Critical White Studies: Looking Behind the Mirror. Edited by Richard Delgado and Jean Stefancic. Philadelphia: Temple University Press, pp. 255-57.

Junior, Nyasha. 2020. The Mark of Cain and White Violence. Journal of Biblical Literature 139: 661-73.

Katongole, Emmanuel M., and Jonathan Wilson-Hartgrove. 2009. Mirror to the Church: Resurrecting Faith after Genocide in Rwanda. Grand Rapids: Zondervan.

Kendi, Ibram X. 2016. Stamped from the Beginning: The Definitive History of Racist Ideas in America. New York: Nation Books.

Kidd, Colin. 2006. The Forging of Races: Race and Scripture in the Protestant Atlantic World, 1600-49. Cambridge: Cambridge University Press.

Knust, Jennifer. 2014. Who's Afraid of Canaan's Curse? Biblical Interpretation 22: 388-413. [CrossRef]

Liz, Jordan. 2018. "The Fixity of Whiteness": Genetic Admixture and the Legacy of the One-Drop Rule. Critical Philosophy of Race 6: 239-61. [CrossRef]

McEntire, Mark, and Wongi Park. 2021. Ethnic Fission and Fusion in Biblical Genealogies. Journal of Biblical Literature 140: 31-47.

McKenzie, Steven L. 1997. Response: The Curse of Ham and David H. Aaron. Journal of the American Academy of Religion 65: 183-86. [CrossRef]

McLeod, Alexander. 1863. Negro Slavery Unjustifiable: A Discourse. New York: Alexander McLeod.

Mirón, Louis F., and Jonathan Xavier Inda. 2000. Race as a Kind of Speech Act. Cultural Studies 5: 85-107.

Palmer, Benjamin M. 1856. The Import of Hebrew History. Southern Presbyterian Review 9: 582-610.

Palmer, Benjamin M. 1859. "Our Historic Mission" An address delivered before the Eunomian and Phi-Mu societies of La Grange Synodical College, July 7, 1858. New Orleans: “True Witness" Office.

Park, Wongi. 2019. The Politics of Race and Ethnicity in Matthew's Passion Narrative. Cham: Palgrave MacMillan.

Perry, Rufus L. 1887. The Cushite; or, the Children of Ham, (the Negro Race) as Seen by the Ancient Historians and Poets. New York: The Literary Union.

Peterson, Thomas Virgil. 1978. HAM AND JAPHETH: The Mythic World of Whites in the Antebellum South. Metuchen: The American Theological Library Association.

Postma, Johannes. 1990. The Dutch in the Atlantic Slave Trade, 1600-1815. Cambridge: Cambridge University Press.

Powery, Emerson B., and Rodney S. Sadler Jr. 2016. The Genesis of Liberation: Biblical Interpretation in the Antebellum Narratives of the Enslaved. Louisville: Westminster John Knox.

Priest, Josiah. 1852. Bible Defence of Slavery and Origin Fortunes, and History of the Negro Race. Glasgow: Rev W. S. Brown, M.D.

Ramey, Lynn T. 2014. Black Legacies: Race and the European Middle Ages. Gainesville: University Press of Florida.

Rankin, John. 1833. Letters on American Slavery Addressed to Mr. Thomas Rankin, Merchant at Middlebrook. Boston: Augusta Co., Va. 
Reed, Justin. 2020. Noah's Curse and the Presumption of Canaanite Guilt: A New Reading of Genesis 9:18-29. Ph.D. dissertation, Princeton Theological Seminary, Princeton, NJ, USA.

Rhys, Morgan John. 1798. Letters on Liberty and Slavery. In Answer to a Pamphlet Entitled, "Negro Slavery Defended by the Word of God", 2nd ed. New York: R. Wilson.

Sadler, Rodney S., Jr. 2005. Can a Cushite Change His Skin? An Examination of Race, Ethnicity, and Othering in the Hebrew Bible. New York: T\&T Clark.

Sadler, Rodney S., Jr. 2006. Can a Cushite Change His Skin? Interpretation 60: 386-403. [CrossRef]

Schaff, Philip. 1861. Slavery and the Bible. A Tract for the Times. Chambersburg: M. Kieffer \& Co.'s Caloric Printing Press.

Schipper, Jeremy. 2020. Religion, Race, and the Wife of Ham. The Journal of Religion 100: 386-401. [CrossRef]

Sloan, James A. 1857. The Great Question Answered; or, Is Slavery a Sin in Itself (per se?) Answered according to the Teaching of the Scriptures. Memphis: Hutton, Gallaway \& Co.

Speke, John Hanning. 1864. Journal of the Discovery of the Source of the Nile. New York: Harper \& Brothers Publishers.

Stringfellow, Thornton. 1841. A Brief Examination of Scripture Testimony on the Institution of Slavery. Locust Grove: Culpepper Co., Va.

Stringfellow, Thornton. 1856. Scriptural and Statistical Views in Favor of Slavery, 4th ed. Richmond: J. W. Randolph.

Stringfellow, Thornton. 1861. Slavery: Its Origin, Nature, and History considered in the light of Bible Teachings, Moral Justice, and Political Wisdom. New York: John F. Trow Printer 50 Greene St.

Sussman, Robert Wald. 2014. The Myth of Race: The Troubling Persistence of an Unscientific Idea. Cambridge: Harvard University Press.

Sweet, Frank W. 2005. Legal History of the Color Line: The Rise and Triumph of the One-Drop Rule. Palm Coast: Backintyme.

Teel, Karen. 2012. What Jesus Wouldn't Do: A White Theologian Engages Whiteness. In Christology and Whiteness: What Would Jesus Do? Edited by George Yancy. London: Routledge, pp. 19-36.

Twain, Mark. 1894. Pudd'nhead Wilson. New York: Grove Press.

U.S. Census Bureau. 1922. Fourteenth Census of the United States, 1920, Volume 3; Washington, DC: Government Printing Office.

Van Amringe, William Frederick. 1848. An Investigation of the Theories of the Natural History of Man by Lawrence, Prichard, and Others: Founded upon Animal Analogies and an Outline of a New Natural History of Man Founded upon History, Anatomy, Physiology and Human Analogies. New York: Baker \& Scribner.

Weld, Theodore Dwight. 1838. The Bible against Slavery. An Inquiry into the Patriarchal and Mosaic Systems on the Subject of Human Rights, 4th ed. New York: American Anti-Slavery Society.

Whitford, David M. 2009. The Curse of Ham in the Early Modern Era: The Bible and the Justifications for Slavery. Burlington: Ashgate.

Whitford, David. 2010. A Calvinist Heritage to the 'Curse of Ham': Assessing the Accuracy of a Claim about Racial Subordination. Church History and Religious Culture 90: 25-45. [CrossRef]

Wynter, Sylvia. 2003. Unsettling the Coloniality of Being/Power/Truth/Freedom: Towards the Human, After Man, Its Overrepresentation-An Argument. CR: The New Centennial Review 3: 257-337. [CrossRef] 